\title{
Recent Advancement in Proportioning of No-fine Concrete - Review
}

\author{
Rekha Singh ${ }^{1}$, Sanjay Goel $^{2}$ \\ ${ }^{\prime} I K G$ Punjab Technical University, Jalandhar, Punjab, India. \\ ${ }^{2} \mathrm{DAV}$ Institute of Engineering and Technology, Jalandhar, Punjab, India.
}

'Email: rekhasingh14@gmail.com

\section{ARTICLE INFORMATION}

DOI: $10.15415 /$ jotitt.2019.71001

Keywords: Durability, Supplementary cementitious material, Mechanical strength, Microstructure, Porosity, Permeability

\begin{abstract}
The paper highlight characteristics of no fine concrete (NFC) by evaluating and interpreting the research work undertaken by research scholars around world in past. It explains the approach for better performances. It helps to understand and identify the difference between knowledge and actual performance on ground which stops it from wide and acceptable application throughout the globe. A comprehensive investigation of proportioning of no fine Concrete has been discussed. Identification of relationship between mechanical properties with its design and pore structure of $\mathrm{NFC}$ will help us in studying ways of its better utilization. The specific reference has been made for India to understand level of research \& development in laboratories and status of different applications at different levels.
\end{abstract}

\section{Introduction}

No fine concrete (NFC) is composed of large aggregates which allow water to infiltrate into ground from surface. In cities, every major road and shoulder drains are topped with normal concrete. The rainwater has no space to percolate down to the soil and ground water is not being recharged. The pavement tiling projects enclose trees completely, unable to spread their roots, the trees do not last long enough and also weaken the footpath. Not only are the trees put to strain but also the water heads off as storm water through the drains instead of seeping into the ground. The drying up of groundwater affects the trees and strains their growth. Storm water drain overflow is leading to urban floods and water logging.
Considerable volume of rain water flow on impervious roadway, parkways and street roads is not absorbed by soil. Such waste of water disturbs the natural balance of ecosystem and results in frequent floods, thinning of ground water table and pollution of rivers. The obvious solution is to use NFC on broad scale. The traditional concrete should be converted to porous or NFC to the extent possible. Such NFCs function as natural filters by absorbing pollutant loads and stopping them from flowing into water channels. NFC has low unit weight compared to normal concrete. It is unique in terms of porosity and cement matrix is the dominating factor to provide strength [1]. The voids in macrostructure allow water to percolate through. It is cheap as far as costs 
are concerned. It has high thermal insulation value as reflected in Fig. 1.

The potentiality of NFC in allowing water to flow rapidly is top characteristic followed by its strength to carry loads. Until now, the term permeability has not been specified leading to confusion of how much permeable, permeable concrete is. Initial good permeability might reduce with time due to clogging. Although, the industry is moving toward design permeability but lack of comprehensive data and understanding about behavior of porosity and infiltration test is a hindrance [2]. NFC absorbs UV \& heat rays and help in reduction in temperature [3]; however it is subject to regular care for long term benefits.

The present review paper helps us in understanding the proportioning stated by different authors and looking out for avenues for application of NFC. Fig. 2 shows the observed results.

\section{Challenges in application of permeable pavements}

Permeable pavement systems (PPS) have wide applications ranging from residential houses to commercial factories but due to below mentioned challenges the usage is very less and irregular. These have very low strength if compared with normal concrete pavement systems. The amount of damage and time period of damage makes builders reluctant to use it. Due to this the usage has been for light utility only. The early strength development is essential in case of $\mathrm{PC}$ as the

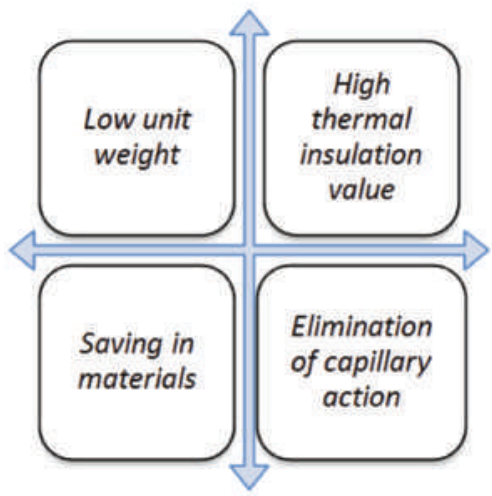

Figure 1: Benefits of using NFC

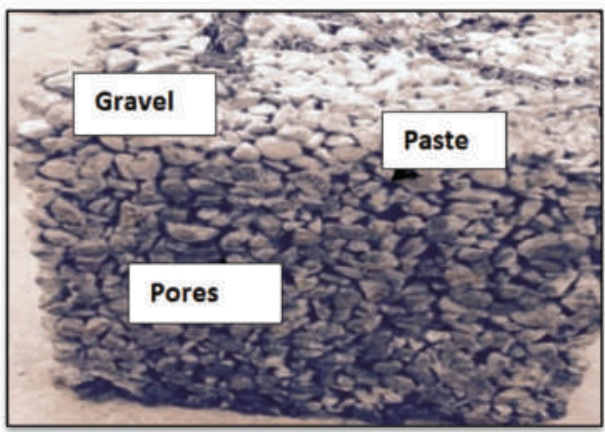

Figure 2: Photographic view of no-fine concrete 
road need to be open for traffic at a time limit of 7 days [4]. Some exercise need to be done to achieve early strength, adding mineral admixtures or polymer modification with sufficient water drainage capacity.

The comprehensive data to access particular strength is not available. A full proof system for measuring level and quantum of permeability is still not available. The pavement tends to clog very early compromising its applicability to a large extent. The pollutants percolate through the voids and reach ground water and affect the ecosystem negatively. The maintenance efforts and cost are very high which reduces economic viability.

Many researchers [5,6] have done detailed study and [7-9] have proposed technical guidelines still lack of authentic central technical warehouse and access to it has resulted in some failures [10] of NFC in practical applications. [11,12] .Have also tried to understand traffic loads for NFC with falling weight deflectometer, but further research is required in this. The wide-range of research on (PPS) was also summarized [13] which highlight the current scenario in research and industry and recommends the future avenues of research and development. In one of the available pilot study [14], higher raveling was observed in turning zones compared to driving and parking ones but the permeability was observed to be satisfactory although the compressive strength was low. Haselbach and Freeman [15] investigated vertical porosity distribution within a field placed NFC slab to understand clogging and ways of maintenance and inferred that porosity reduction was highest at top. The property is beneficial since clogging at top provide an opportunity to clean it through vacuuming for regular maintenance. There are many problems surrounding the measurement of quality in NFC pavements. The problems exist because the material properties and their sensitivity to variations, which occur in consolidating and curing [16].

\section{History of no-fine concrete application}

Pervious concrete has been used in the past in the various parts of the world for building constructions before World War II. After 1946 NFC was utilized for variety of applications [1]. Brief history of no fine concrete is shown with the help of diagram in Fig. 3.

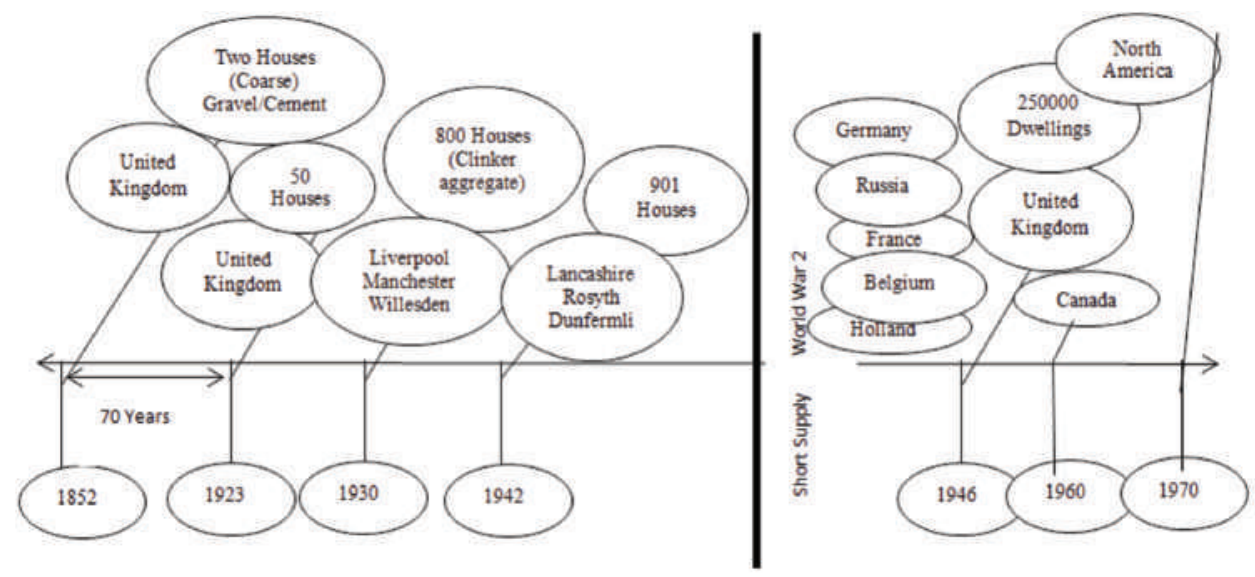

Figure 3: History of application of NFC 


\section{Materials and its properties used in making NFC}

\subsection{Aggregates}

In accordance with ASTM D448 [17], single size or gradation in between (19-9.5mm) aggregate are generally utilized in the making of NFC from NA and LWA. The NA to be used in NFC should be free from dust or clay particles and any type of coating of chemical that can decrease the strength of bond between cement matrix and aggregates.

The effect of shapes and size of aggregates was determined on the permeability of NFC [18]. The result found indicates that aggregate with less angularity number produce mix having low permeability. Neptune and Putman [19] reported that unit weights of aggregates should be determined in accordance with ASTM C29/C29M [20]. The mechanical strengths of NFC increases with the coefficient of uniformity $(\mathrm{Cu})$ to a point after which it decrease. In one of the studies [21] it was reported that, if we use high quantity of small aggregates (4-8 mm), then we can achieve higher density and flexural strength of concrete.

Gaedicke et al. [22] investigated three types of aggregates and found their effect on porosity and abrasion resistance. Use of RCA in NFC decreases the unit weight as reported by Kim and lee [23], but increases its environmental benefits [24, 25]. Previous stud- ies indicated that waste material can also be successfully utilized as a substitute of natural aggregate to produce NFC. For example Nguyen et al. [26] utilized sea shell by-products in partial replacement of aggregates in NFC both as an environment friendly building material and a potential component.

Kuo et al. [27] reported that the Washed municipal solid waste incinerator bottom ash (MSWIBA) of maximum size $12.5 \mathrm{~mm}$ used as a replacement of NA does not cause any significant difference in connected porosities, compressive strength and permeability coefficient. Different approaches have been used by the researchers in making NFC with Recycle aggregate in different replacement levels are shown in Table 1.

Replacement of NA with RCA, increase the porosity and permeability. Bhutta et al [28] reported that by polymer modification, the compressive strength of $\mathrm{NA}$ and RCA increase by 1.57 and 1.79 times respectively.

The weak cement matrix and interfacial transition zone among gravels in recycled aggregate concrete which causes compressive strength to decrease in case of traditional concrete [29].

It is also found that the use of LWA in NFC, decrease the unit weight and thermal conductivity which makes it suitable for use as insulating concrete; however, compressive strength improved significantly [30,31].

Table 1: No-fine concrete made with recycle aggregate

\begin{tabular}{|l|l|l|}
\hline \multicolumn{1}{|c|}{ Author } & $\begin{array}{l}\text { RCA \% / Miner- } \\
\text { al Admixture }\end{array}$ & \multicolumn{1}{c|}{ Major findings } \\
\hline $\begin{array}{l}\mathrm{Li}[34] \text { \& Rizvi } \text { et } \\
\text { al. [35] }\end{array}$ & RCA 15\% & $\begin{array}{l}\text { No substantial difference visible between two } \\
\text { natural and Recycle Coarse Aggregate. }\end{array}$ \\
\hline Bhutta et al. [60] & $\begin{array}{l}\text { RCA } 100 \%+ \\
\text { Polymer }\end{array}$ & $\begin{array}{l}\text { Gain in void ratio and water permeability, } \\
\text { augmentation of mechanical strength by use of } \\
\text { polymer. }\end{array}$ \\
\hline
\end{tabular}

ISSN No.: 232 1-3906 (Print) ISSN No.: 2321-7146 (Online) Registration No.: CHAENG/2013/51235 Periodicity: Bi-Annually 


\begin{tabular}{|c|c|c|}
\hline \multicolumn{3}{|c|}{ Table 1 [Continued] } \\
\hline Author & $\begin{array}{l}\text { RCA \% / Miner- } \\
\text { al Admixture }\end{array}$ & Major findings \\
\hline $\begin{array}{l}\text { F. Tittarelli et al. } \\
\text { [38] }\end{array}$ & RCA $100 \%$ & $\begin{array}{l}\text { Capillary water absorption increased by } 100 \% \\
\text { but mechanical performance decreased by } 30 \% \text {. }\end{array}$ \\
\hline Gaedicke et al. [9] & RCA $50 \%$ & $\begin{array}{l}\text { Porosity increased by } 20 \% \text { but mechanical per- } \\
\text { formance decreased by } 8 \% \text {. }\end{array}$ \\
\hline $\begin{array}{l}\text { Guneyisi et al. } \\
{[142]}\end{array}$ & $\begin{array}{l}\text { RCA } 25 \%, 50 \% \\
75 \%, 100 \%\end{array}$ & $\begin{array}{l}\text { Augmentation of permeability coefficient, de- } \\
\text { cline in unit weight and mechanical properties. }\end{array}$ \\
\hline Gaedicke et al. [9] & $\begin{array}{l}\text { RCA } 50 \%+ \\
\text { GGBFS }\end{array}$ & $\begin{array}{l}\text { RCA and GGBFS have no impact on abrasion } \\
\text { resistance. }\end{array}$ \\
\hline $\begin{array}{l}\text { Z. Zhang et al. } \\
{[145]}\end{array}$ & $\begin{array}{l}\text { RCA } 100 \%+\text { Fly } \\
\text { Ash }\end{array}$ & $\begin{array}{l}\text { Addition of Recycle clay brick aggregate in- } \\
\text { creased crushing index but decreased compres- } \\
\text { sive, flexure strength and elasticity modulus by } \\
36 \%, 28 \% \text { and } 21 \% \text { respectively ( } 28 \text { days). }\end{array}$ \\
\hline
\end{tabular}

\subsection{Cementitious materials}

Ordinary Portland cement has been generally used as major binder in making concrete. Industrial wastes like FA, slag and SF can also be used in addition to Portland cement and should meet the requirements of ASTM standards. Aspects such as rate of strength development, setting time and permeability also need to be studied for respective SCM.

Partially replacing OPC with MA like FA, $\mathrm{SF}$, and RHA is also well researched. The thickness of cementitious layer is in direct relationship with mechanical and hydrological properties of NFC. Yang and Jiang [32] found that compressive strength of more than $45 \mathrm{MPa}$ and flexural strength of more than $5 \mathrm{MPa}$ could be achieved by the addition of Silica fume, and using smaller size aggregate. Yang [33] found that there is increase in performance against Freeze-thaw résistance with the addition of silica fume. The RHA and fiber has been observed to increase the mechanical properties [34]. It was also reported by Zhong \& wille [35] that the strength of cement, size of aggregates and aggregate to binder $(\mathrm{a} / \mathrm{b})$ ratio largely modify the strength properties. Also, the film forming ability was determined [36] in terms of paste thickness, and reported that the large size aggregate make thicker film compared to small aggregate size. The required amount of paste in NFC can also be estimated from the paste thickness. Large size aggregate has more paste thickness as compared to the small size aggregates. The strength properties increase as the size of aggregate decrease which increases the binding area.

\subsection{Admixtures}

Water reducing admixtures depend on the w/c for mixing [1]. Retarding admixtures are generally required while making stiff paste like in case of NFC. They are specifically helpful in hot weather application. Some admixture like Retarding admixtures are used during moulding process to act as lubricant and helping in taking the mix out easily. Accelerators are helpful when NFC is placed in cold environment. Many studies have reported the use of viscosity modifying agent (VMA) (in accordance with ASTM C494) with water reducing agent to modify the fresh properties of NFC [22, 142, 143]. 
Air entraining admixtures are often used in NFC. When used in environment susceptible to freezing and thawing, it has shown good resistance. As widely reported [38-40], the experimental investigation explored the effect of air entraining admixtures and reported that water to cement $(\mathrm{w} / \mathrm{c})$ ratio less than 0.40 , entrained air bubbles are not required since the paste matrix are more resistant to freeze-thaw action but further corroboration is required to validate this.

\subsection{Mix proportions}

The material used for mix proportioning of NFC is combination of Portland cement, with uniform or binary combination of coarse aggregate, miniscule fine aggregates by weight of total aggregate and water [41]. As widely reported by many researches $[4,21,32,34$, $143,42-46]$, with the increase of little amount of fine aggregate as sand, the compression strength, durability and resistance against $\mathrm{F} / \mathrm{T}$ tend to enhance. Generally PC consists of $270-415 \mathrm{~kg} / \mathrm{m} 3$ of cement, $1190-1480 \mathrm{~kg} /$ $\mathrm{m} 3$ of aggregate and w/c ratio from $0.26-$ 0.40. The 28 days compressive strength varies from 3.5-28 MPa, hydraulic conductivity in the range $0.2-5.4 \mathrm{~mm} / \mathrm{s}$ and pore size $2-8 \mathrm{~mm}$, depending on the type of aggregate and compaction technique used.
From past research studies it is seen that $\mathrm{NFC}$ can be produced by varying the $\mathrm{w} / \mathrm{c}$ ratio, a/c ratio, size of aggregate and binder material type shown in Table 2. From the past studies it is found that NFC mix proportions are selected from experimental basis; however, the numbers of proposed studies on mix design of NFC are very less. The design methods reported in past literature have many disadvantages [1, 47-49] for e.g. they do not indicate how to determine the $\mathrm{w} / \mathrm{c} \mathrm{ra-}$ tio or effect of compaction on properties of concrete has not been taken into consideration as well there are no appropriated technique to determine the mix design of NFC.

Nguyen et al. [26] proposed the mix design for NFC based on the presumption that the cementitious paste acts only as a coating. Based on the hypothesis, required w/c, aggregate volume, cement paste volume were calculated. Binder drainage test was also proposed to evaluate the $\mathrm{w} / \mathrm{c}$ ratio so that the cement paste does not go down the lower layers of concrete. To obtain empirical equation for mixture design, Zhangi et al [48] recommended orthogonal test. According to the Talbot's formula and previous experience, the orthogonality test was designed with consideration of three factors - cement dose, water cement ratio and aggregate gradation with four levels each.

Table 2: Summary of mix proportions of NFC from past literature (recreated as in [16])

\begin{tabular}{|l|c|c|c|c|c|c|}
\hline References & Year & $\begin{array}{c}\text { Cementitious } \\
\text { Material }\left(\mathbf{k g} / \mathbf{m}^{3}\right)\end{array}$ & $\begin{array}{c}\text { Aggregates } \\
\left(\mathbf{k g} / \mathbf{m}^{3}\right)\end{array}$ & W/CM & $\begin{array}{c}\text { Agg./cm } \\
\text { ratio }\end{array}$ & $\begin{array}{c}\text { Water } \\
\left(\mathbf{k g} / \mathbf{m}^{3}\right)\end{array}$ \\
\hline $\begin{array}{l}\text { Khankhaje } \text { et } \\
\text { al. }[50]\end{array}$ & 2016 & 340 & 1460 & 0.32 & - & 109 \\
\hline $\begin{array}{l}\text { Chandrappa } \\
\text { et al. }[51]\end{array}$ & 2016 & $321-487$ & $1373-1692$ & $0.25-0.35$ & $3.0-5.0$ & $84-161$ \\
\hline $\begin{array}{l}\text { Yahia and } \\
\text { Kabagire } \\
{[52]}\end{array}$ & 2014 & $195-535$ & $1500-1700$ & 0.30 & - & - \\
\hline
\end{tabular}

ISSN No.: 232 1-3906 (Print) ISSN No.: 2321-7146 (Online) Registration No.: CHAENG/2013/51235 Periodicity: Bi-Annually 


\begin{tabular}{|l|c|c|c|c|c|c|}
\hline \multicolumn{7}{|c|}{ Table 2 [Continued $]$} \\
\hline References & Year & $\begin{array}{c}\text { Cementitious } \\
\text { Material }\left(\mathbf{k g} / \mathbf{m}^{3}\right)\end{array}$ & $\begin{array}{c}\text { Aggregates } \\
\left(\mathbf{k g} / \mathbf{m}^{3}\right)\end{array}$ & W/CM & $\begin{array}{c}\text { Agg./cm } \\
\text { ratio }\end{array}$ & $\begin{array}{c}\text { Water } \\
\left(\mathbf{k g} / \mathbf{m}^{3}\right)\end{array}$ \\
\hline $\begin{array}{l}\text { Nguyen et } \\
\text { al.[46] }\end{array}$ & 2013 & 309 & 1525 & 0.30 & 4.9 & 93 \\
\hline $\begin{array}{l}\text { Lim et al. } \\
{[53]}\end{array}$ & 2013 & $242-495$ & 1560 & $0.20-0.30$ & $3.15-6.44$ & $\begin{array}{c}73.4- \\
148.5\end{array}$ \\
\hline $\begin{array}{l}\text { Bassuoni } \\
\text { and Sonebi } \\
{[54]}\end{array}$ & 2010 & $315-415$ & $1200-1400$ & $0.28-0.40$ & $4-6$ & $125-154$ \\
\hline $\begin{array}{l}\text { Huang et al. } \\
{[42]}\end{array}$ & 2010 & $320-353$ & $1440-1587$ & 0.35 & 4.5 & $\begin{array}{c}112.1- \\
123.4\end{array}$ \\
\hline $\begin{array}{l}\text { Neithalath } \\
\text { et al. [55] }\end{array}$ & 2010 & $309-312$ & $1544-1568$ & 0.33 & 5 & $101-104$ \\
\hline $\begin{array}{l}\text { Kevern et al. } \\
{[56]}\end{array}$ & 2010 & 340 & 1540 & 0.27 & 4.53 & 100 \\
\hline $\begin{array}{l}\text { Crouch et al. } \\
{[57]}\end{array}$ & 2007 & $287-345$ & $1542-1620$ & 0.30 & $4.5-5.6$ & $87-105$ \\
\hline $\begin{array}{l}\text { Ghaffori et } \\
\text { al. [58] }\end{array}$ & 1995 & $300-413$ & $1651-1800$ & $0.37-0.42$ & $4-6$ & $125-154$ \\
\hline
\end{tabular}

Joshaghani et al. [59] utilized the Taguchi method for designing the NFC pavement to optimize the mix design. The study determined that strength is mainly governed by the void ratio and increase in maximum size of aggregates, as the void ratio surge, the strength of single size aggregate decline. As stated in the study, the most dominating factors in compressive strength are the quantity of paste and in tensile and flexural strength is the size of aggregate.

Several successful attempts have been made on the mix design for NFC (provided in Table 2) and concluded that adequate combination of mix ingredients in NFC gives the required strength and durability. The network of interconnected voids of aggregate coated with stiff paste should be maintained.

\section{Fresh properties of NFC}

\subsection{Unit weight}

Fresh state of NFC is a function of workability, unit weight and porosity and it is affected mainly by water to cement ratio, workability and properties of aggregates used. Aggregate in concrete is a big factor with type, size and water absorption playing crucial roles. Sometimes, it is very difficult to obtain workable NFC of required porosity due to zero slump loss in it. Physical properties of aggregate like size, shape, texture affect workability in major way.

Unit weight of NFC is imperative instrument which helps in deciding the plastic state. There are no standard methods available to determine the unit weight; moreover, the unit weight is one of the best available measures for quality control of NFC mixtures. It is common to compact NFC by jigging in accordance with ASTM C29 [20] and the National Ready Mix Concrete Association (NRMCA) [60]. In a study by Tennis et al. [61] reported that field practices can have the acceptance of a NFC mixture of unit weight $80 \mathrm{~kg} / \mathrm{m}^{3}$ 
or $+/-5 \%$ tolerance factor is acceptable for field practices. The effect of two methods of compaction namely rodding and jigging on unit weight were also analyzed. Neptune and putman [19] observed that jigging resulted in higher unit weight for all the mixtures within $9.5 \mathrm{~mm}$ gradation and mixtures with $\mathrm{Cu}$ closer to 3 and above. On the other hand, the rodding procedure produced higher values for the mixtures with lower $C u$ values in the $12.5 \mathrm{~mm}$ and $19.0 \mathrm{~mm}$. Also, Gaedicke et al. [62] calculated the unit weight described in ASTM C1754 and used proctor hammer for compaction.

Unit weight and porosity are directly related to each other. As the porosity increases, density decreases and vice versa, also if the density of NFCs goes up, the porosity and water permeability goes down [63, 64]. Moreover, Murray et al. [65] reported that material properties are function of porosity of concrete mix. The final concrete unit weight is highly impacted by unrodded unit weight of aggregate. ASTM C1688 is commonly used to calculate the density and voids content in NFC. The effective voids present in NFC decrease significantly by increasing fine aggregate and water content, ultimately increases the average compressive strength [66].

\subsection{Porosity/Pore sizes}

Porosity is also one of the main properties of NFC and directly affects the mechanical and durability properties [67]. In NFC the total porosity/void content can be determined as per ASTM C1688 [68]. It can also be measured by using the method developed by Montes et al. [69] conforming to ASTM C1754 [70] and this method is widely reported by many researchers $[34,51$, $52,62,63,71,72]$ while several researchers $[19,72-75]$ have also used the method described in ASTM D7063 [76] to calculate the effective porosity. Zhong and wille [35] used difference between saturated and oven dried weight to calculate effective porosity. It was also reported that higher percentage of coarse aggregate resulted in a higher porosity [21]. This may be due to fact that void by FA cannot be filled by CA.

Deo and Neithalath [77] reported a reduction in porosity of the NFC mixtures with the increase in the compressive energy absorbed. As per Kim and lee [23], the total void ratios of specimen are more when smaller size aggregates are used. Moreover, Meulenyzer et al. [78] reported that paste volume and aggregate size have strong influence on pore parameters like pore size diameter and image analysis is helpful to understand the association between pore structure and permeability of the materials. The porosity is the decisive factor for quality control in pavement design and for material comparison. The error between different equipment's readings in separate labs but using similar Archimedes principle was 2.2\% [69]. The porosity is an important parameter and mainly depends on field placement techniques so it was also recommended to calculate the porosity of field-placed specimens based on the aggregate size, core size and porosity [67]. A study also reported that porosity is greatly affected by recycle aggregate.

Bhutta et al. [79] in their study mentioned that the porosity is influenced by the addition of super plasticizer and a thickening agent for high performance NFC.

Vertical porosity distribution was also determined but earlier it was assumed to be constant along the depth [73, 80]. Their experimental investigation reported that the porosity increases significantly from top to bottom being lowest porosities in the top quarter, average porosities in the center half, and the higher porosities near the bottom. 
Various stereological and morphological techniques were used to determine the distribution of pores in NFC [55]. Lian et al. [81] proposed mathematical model that provide relation between porosity and compressive strength. Zhong and wille [82] reported the pore size distribution derived by linear path function follows image analysis correctly. the mathematical model to predict compressive strength based on porosity.

Many researchers are delved into evaporation rate studies from different types of pavements.

H. Li et al. [85] provided an easy technique to determine evaporation rate with adequate size of pore and capillary effect for different types of pavements. It was reported that to increase the evaporation and cooling effect, (a)

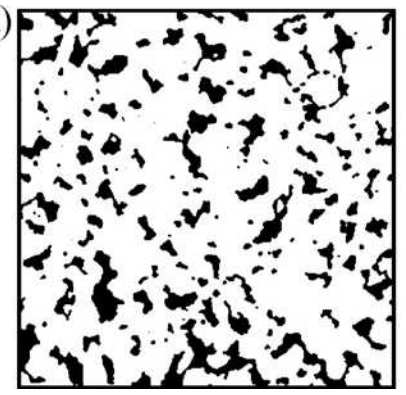

(b)

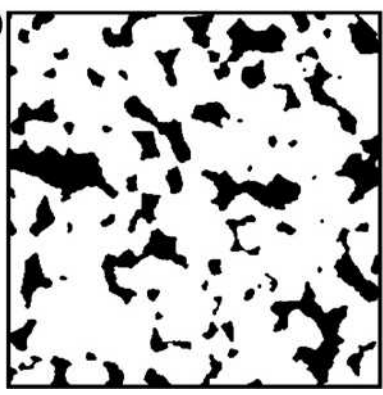

(c)

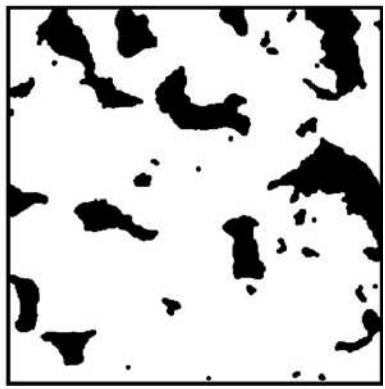

Figure 4: Images of 2D sections of NFC specimens made with: (a) $100 \% 4.75 \mathrm{~mm}(\#) 8$; (b) $100 \% 9.5 \mathrm{~mm}(\# 4)$; and (c) $100 \% 12.5 \mathrm{~mm}(\# 3 / 8)$ aggregates (black spots are the pores) [83].

Deo et al. [83] found reduction in porosity with an increase in the compressive energy absorbed by compactive efforts in NFC mixtures. The size of pores increase with increase in size of aggregate. The mixes can have the similar porosity or identical porosity regardless of the nominal maximum size of aggregate used. The size of pores will increase with large size aggregate (12.5) (Fig. 4) and large no of small pores in small size aggregate $(4.75 \mathrm{~mm})$ and combination of large and small pores in $(9.5 \mathrm{~mm})$. Cosic et al. [21] reported that to produce large size pores, large aggregate could be used resulting into higher value of overall porosity but it also reduce the chance of clogging. Large amount of smaller size fraction $(4-8 \mathrm{~mm})$ increase the density and strength properties in PC. Lian and Zhuge [84] developed mathematical model to correlate compressive strength and porosity and studied through empirical and theoretical derivations. Experimental data was in good agreement with the pavement should have sufficient permeability and the evaporation rate was 0.1$0.3 \mathrm{~mm} / \mathrm{hr}$ although earlier Syrrakou et al. [86] reported evaporation rates of magnitude $\left(10^{-2} \mathrm{~mm} / \mathrm{h}\right)$.

\section{Hardened properties of NFC}

\subsection{Compressive strength}

The compressive strength is inversely correlated to permeability [34, 57,132]. It is also observed that the compressive strength of the NFC increases linearly with the increase of the tensile strength [30]. It has been observed that addition of small amount of sand was efficient in increasing mechanical property $[2,6,92]$. It is also reported that addition of sand and latex enhance the mechanic strength but reduce permeability of NFC [131]. The mixes with only sand, had higher increase in strength than the mixtures with sand and latex. 
As the aggregate size increase, the mechanical strengths decline, but these differences were not statically significant [57,132]. The mechanical strength is strongly related to mix proportion [23] and porosity of $\mathrm{NFC}[140]$. Shu et al. [62] reported higher compressive strength using limestone aggregate and incorporation of latex. Also, reported by H. Wu et al [64] adding latex desirably improved the strength whereas addition of fiber did not had visible effect on mechanical properties of NFC. Huang et al. [42] mentioned in their study that addition of polymer, sand, fiber enhance the mechanical strength. Giustozzi [87] mentioned in their study that polymer modified mixes showed delayed curing but the mechanical strength is significantly improved. It was also observed that NFC reached 80-90 \% of compressive strength after 7 days of curing as observed after 28 days of curing [88]. Widely reported by many researchers [52, 89, 90] that the increase in paste volume resulted in improving the mechanical properties regardless of aggregate size and for a given paste volume the use of lower maximum size aggregate resulted in higher strength values. Deo and Neithalath [83] used image analysis method to study material structure and compressive response. The result indicate that using the large size aggregate and increase in paste volume content in NFC are observed to be increase the compressive strength and it is mainly influenced by the pore sizes, their distribution and spacing. Moreover, small size fraction of aggregate produce small size pores in NFC [90]. Many researchers have reported that higher compressive strength could be achieved for mixtures containing smaller size aggregate [91, 21,35, 32,59,92] and increase in cement paste $[30,52,89]$. It is also observed that compressive strength increases with decrease in porosity [23]. Also, compressive strength of $35 \mathrm{MPa}$ was reported by Chang et al. [93] using electric arc furnace slag and alkali activated slag cement.

Suozzo and Dewoolkar [94] investigated the effect of sulphur mortar capping and elastomeric pad capping on the compressive strength measurements and found that there is no statically significant difference in compressive strength measurement. Rehder et al. [95] and Huang et al. [42] from their study reported that fibers generally not found to influence the compressive strength to any significant degree, as is expected for conventional concretes also. Among the pore structure features, porosity exerted the maximum influence on compressive strength. However, Rangelov et al. [96] did air curing followed by wet curing and stated that 28 days compressive strength improved. More than 28 days moist curing did not gave significant gain in strength.

Attempts have been made to make the NFC using locally available coarse aggregates i.e. 1st class brick aggregate, crushed stone aggregate and recycled brick aggregate and found that NFC with compressive strength range from 4.5 to $11.72 \mathrm{MPa}$ and permeability from 60 to $15 \mathrm{~mm} / \mathrm{sec}$ can be made [97]. Wu et al. [98] made permeable bricks using incineration bottom ash and found to achieve $20 \mathrm{MPa}$ of compressive strength. From the experimental work it was observed that the permeability coefficient was low as compared to the traditional bricks. Kevern et al. [99] studied 17 different types of aggregates and showed corresponding strengths.

Bhutta et al. [28] from their experimental investigation reported the reduction in compressive strength using recycle aggregate, but the compressive strength significantly increase due to polymer modification for both normal and recycle aggregate. It is believed that the addition of polymer have improved the internal cohesion 
and water retention between cement matrix and aggregate and increased the bonding force between neighboring aggregate particles. Gaedicke et al. [62] found out that compressive strength of RCA found to be $8 \%$ lower than pea gravel and 15\% lower than limestone aggregate for porosity of $20 \%$. Sata et al. [100] used crushed structural concrete and crushed clay bricks aggregates (both are recycle aggregates) to make geopolymer concrete and analyzed that these can be used but strength loose significantly. Although Compressive strength greatly affected by RCA (92). Moreover, Nguyen et al. [41] reported that by partially replacing natural aggregates with sea shell by products, a compressive strength of $15 \mathrm{MPa}$ could be achieved.

Hence, it can be summarized that the strength of $\mathrm{NFC}$ can be increased (with compromise in permeability) by factors such as paste volume, small size aggregates, addition of sand, mineral admixture and mix design. Variation of compressive strength with porosity by using natural aggregate from 11 studies is shown in Fig. 5 and by using recycle aggregate is shown in Fig. 6.

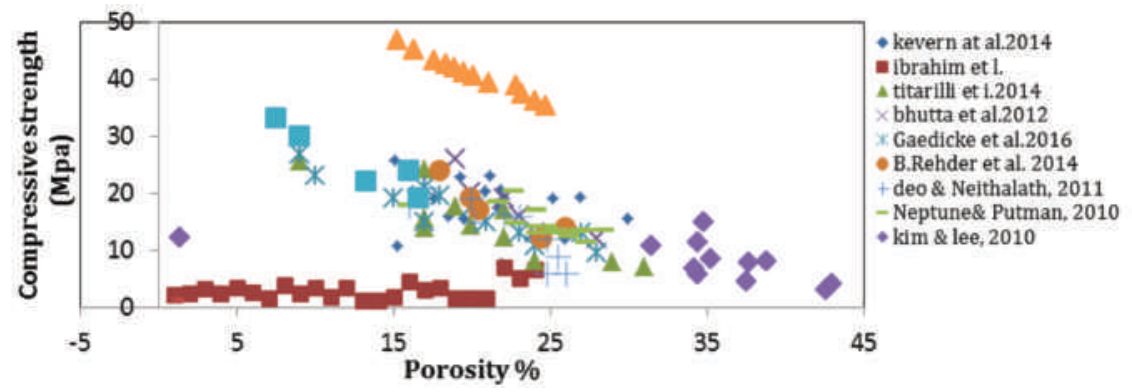

\# w/c-0.3-0.42

Figure 5: Variation in 28 days compressive strength $\mathrm{v} / \mathrm{s}$ porosity reported in previous studies using natural coarse aggregate

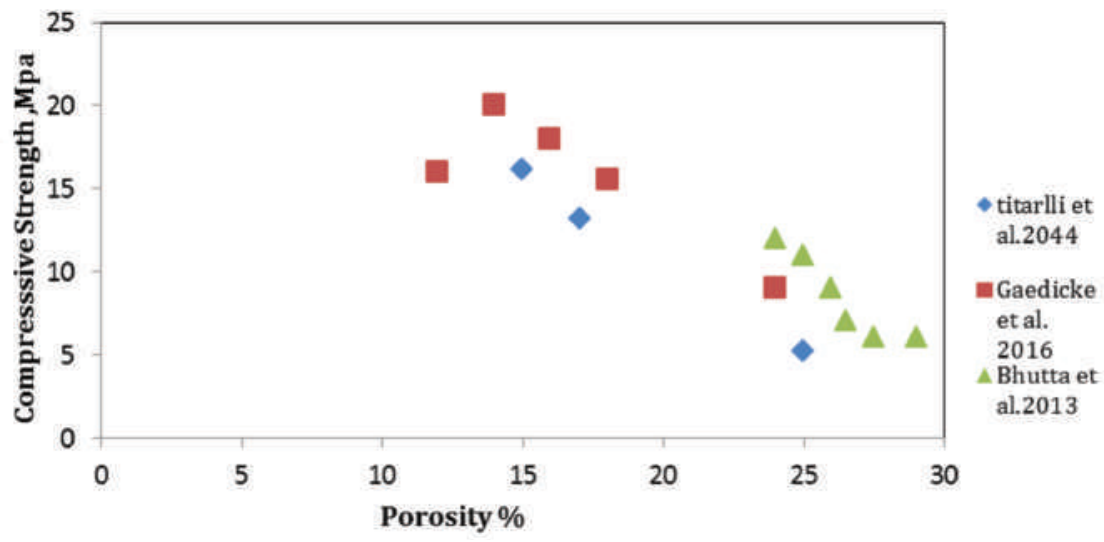

\# w/c-0.3- 0.42

Figure 6: Variation in 28 days compressive strength $\mathrm{v} / \mathrm{s}$ porosity reported in previous studies using recycle coarse aggregate 


\subsection{Split tensile strength and flexural strength}

Crouch et al. [57] mentioned that the strength properties are related to of mixture proportions and are more sensitive to a/c ratio than w/c ratio. Several past investigations have been made on split tensile strength and flexural strength [19, 52, 63, 71]. Shu et al. [38] reported higher split tensile strength using limestone aggregate and incorporation of latex. Neptune and Putman [19] studied fifteen different aggregate gradations to determine the effect of aggregate on NFC properties. The result indicates that split and flexural strength decreased with single size aggregate gradation as the nominal maximum aggregate size increased. In addition to this Maguesvari and Narasimha [44] from their experimental investigation found that the flexural strength and split tensile strength increases with increase in percentage of fine aggregate. Gesoglu et al. [101] studied the effect of rubber aggregate on NFC and found the reduction in split tensile strength mainly due to isolation of aggregate by rubber aggregate from cement paste. The flexural strength of range between 1 to $3.5 \mathrm{MPa}(28$, 34,79). Multiple equation exist from past studies correlating splitting tensile strength, flexural strength and compressive strength for NFC as provided in Table 3; however, very few have developed equation which relate the two properties correctly. These authors have provided a very limited number of specimens for analysis and have taken into account the porosity variation. Although, the behavior of split tensile strength is similar to compressive strength ant its variation with porosity is shown in Fig. 7.

Endeavors have been put on flexural strength to exhibit the effect of recycle aggregate and polymer modification on NFC. The result have shown that the use of recycle aggregate

Table 3: Proposed equation for relationship between compressive strength, split tensile strength and flexural strength for concrete [9]

\begin{tabular}{|c|c|c|}
\hline Reference & Proposed equation & Observation \\
\hline Delatte et al. [102] & $\begin{array}{l}f_{s t}=5 e^{-0.0522 v} \\
f c=62 e^{-0.0677 v}\end{array}$ & $\begin{array}{l}\text { Correlating } f_{s t} \text { and } f_{c} \text { to the void } \\
\text { content of the concrete. }\end{array}$ \\
\hline Crouch et al. [103] & $f_{s t}=0.28(f c)^{0.55}$ & $\begin{array}{l}\text { For NFC, utilized gravel and } \\
\text { limestone }\end{array}$ \\
\hline Ibrahim et al. [63] & $f_{\mathrm{st}}=0.0478+0.1706\left(f_{\mathrm{c}}\right)$ & $\begin{array}{l}\text { For NFC, utilized crushed lime- } \\
\text { stone }\end{array}$ \\
\hline Gaedicke et al.[71] & $\begin{array}{l}f_{s t}=0.181(f c)^{0.875} \\
f_{s t}=0.153(f c)^{0.979}\end{array}$ & $\begin{array}{l}\text { For all types of aggregates and for } \\
\text { effect of specimen type. }\end{array}$ \\
\hline Neptune and Putman [19] & $\begin{array}{l}f_{s t}=0.22(f c)^{0.84} \\
f_{r}=0.63(f c)^{0.47}\end{array}$ & For NFC. \\
\hline Ghafoori and Dutta [58] & $\begin{array}{l}f_{\text {st }}=5.67\left(f_{\mathrm{c}}\right)^{0.5} \\
f_{\text {st }}=5.9\left(f_{\mathrm{c}}\right)^{0.5} \\
f_{\mathrm{st}}=6.15\left(f_{\mathrm{c}}\right)^{0.5}\end{array}$ & $\begin{array}{l}\text { For NFC at } 28,60 \text { and } 90 \text { days of } \\
\text { curing respectively. }\end{array}$ \\
\hline ACI $318[104]$ & $f_{\mathrm{st}}=0.56\left(f_{\mathrm{c}}\right)^{0.5}$ & For conventional concrete. \\
\hline ACI $363[105]$ & $f_{\mathrm{st}}=0.59\left(f_{\mathrm{c}}\right)^{0.5}$ & For high performance concrete. \\
\hline
\end{tabular}


decreased the flexural strength than that of normal aggregate but the polymer modification enhanced the flexural strength in all NFC [79]. Cosic et al. [21] found that flexural strength and modulus of elasticity were higher for dolomite aggregate than steel slag aggregate and increased with higher amount of small aggregate fraction. Brake et al. [37] results indicate the flexural strength depend on size in NFC than in conventional concrete [106]. Kevern et al. [107] reported addition of FA and 5\% sand could increase flexural strength in NFC.

W.T Kuo et al. [27] reported that split tensile and flexure strength is 1:9 and $1: 4$ of the compressive strength by using MSWIBA. Chen at al. [106] reported that flexure strength is predominated by porosity than compressive strength in NFC.

\section{Durability properties}

Generally durability is defined as the surface life under given environmental conditions.
Exposure to chemicals like sulphate, acids etc. and adverse climate condition are the main factors which affects the durability. The microstructure of ITZ depends upon the physical properties of aggregate $[108,109]$. Cement matrix is the only contact between the aggregates strength and durability depends on it. It is well documented in the past literature that contact surface is the weakest point in the concrete from which the propagation of cracks starts. If the surface of aggregate is rough and porous, the bonds will be strong with cement paste [110]. In a study by Vancura et al. [39] Fig. 7, the behavior of NFC was tested as per ASTM C666 and ASTM C457 standard. The crack propagation starts from the contact area between the aggregate and cement paste by separating from surface as shown in Fig. 8.

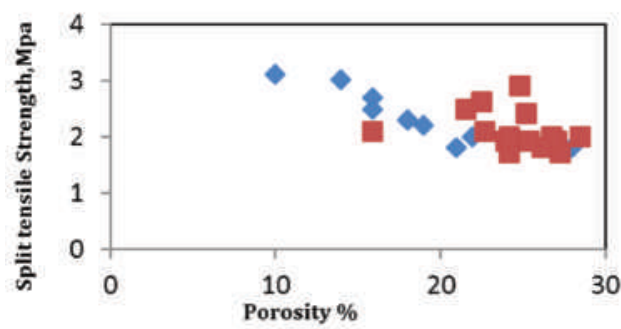

$\checkmark$ Gaedicke et al.2016

Neptune \& Putman,2010

Figure 7: Variation in 28 days split tensile strength $\mathrm{v} / \mathrm{s}$ porosity reported in previous studies using natural coarse aggregate

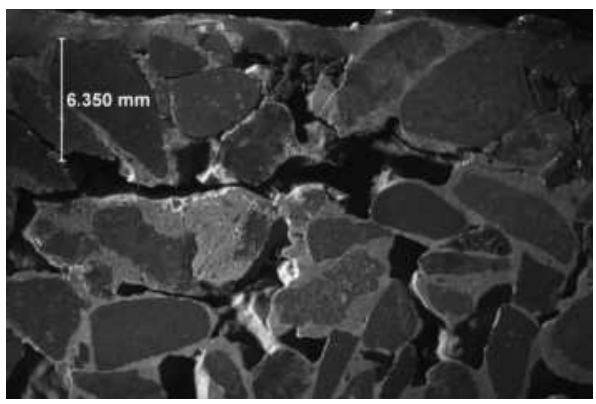

Figure 8: Crack propagation primarily through the ITZ in NFC [39]. 

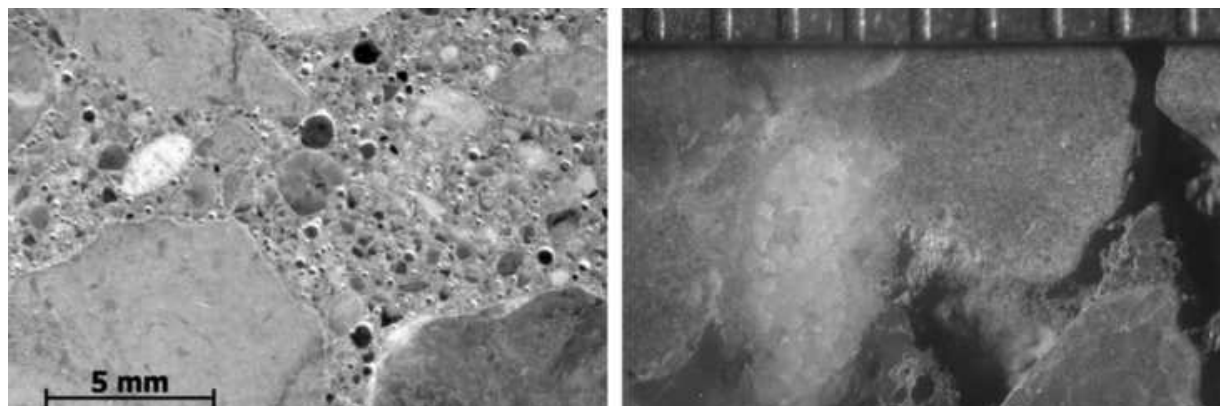

Figure 9: Air-entrained concrete [39] and without entrained air bubbles

\subsection{Freeze thaw resistance}

The resistance to Freeze-Thaw (F-T) cycle is measured as loss in mass after successive number of F-T cycles. The ASTM C666 is used to measure F-T resistance due to lack of standard laboratory practice and more appropriate test is required to assess the durability under F-T condition for NFC [111]. Aggregate properties have the greatest effect on F-T durability. Many experimental studies has reported that use of air-entering admixture improve the F-T durability [38, 39, 58, 99]. Sample field were studied in order to evaluate the F-T. Fig. 9 shows NFC with and without air entering admixture. It was also found that the NFC with w/c below 0.4 may not require entraining bubbles as the paste matrix provides better resistance against $\mathrm{F}-\mathrm{T}$ cycles. NFC mixes with aggregate having higher specific gravity also increase the resistance against F-T [99, 81]. Yang \& Jiang [32] reported that addition of SF and SP increase the $\mathrm{F}-\mathrm{T}$ resistance. In addition to this addition of small amount FA and synthetic fiber also increase F-T resistance. [112]. Yang et al. [113] reported that partially saturated samples compared to submerged samples have improved $\mathrm{F}-\mathrm{T}$ resistance, although salt application increase the disintegration and addition of polypropylene fiber improve the resistance against F-T cycles [33].

\subsection{Abrasion resistance}

Raveling remains one of the prime challenges towards broader application of concrete technology [114]. Portland cement NFC have interconnected voids providing high porosity but at the same time decreasing strength and abrasion resistance.

Several studies have shown that small sized coarse aggregate, fine aggregates, polymer and other chemical admixture improve NFC properties [35, 32, 115]. Spalling and raveling are attributed as two biggest reason of abrasion are tested by cantabro test, loaded wheel abrasion test and surface abrasion tests ASTM C944 [64,116]. Addition of latex enhances the strength in abrasion.

Similarly, Shu et al. [38] also came up with the same investigation by using cantabro method to study abrasion resistance with latex. Incorporating RCA and GGBS did not reduce the abrasion resistance [22]; However, Dong et al. [115] found that surface abrasion test fail to distinguish between latex and fiber incorporated NFC but successful in control mix. Chen et al. [117] studied with help of accelerated abrasion test and inferred that NFC pavement is more durable than normal concrete. The results may vary if the cement type, coarse aggregate type, gradation and mix proportion change. Kevern et al. [107] found the better abrasion with surface cur- 
ing compound but the best resistance against abrasion was obtained with soya bean oil as curing compound.

\subsection{Fracture toughness}

The incorporation of fiber can be selected to increase toughness. In accordance with ASTM C1399 [118], addition of fiber of length 1.5-2 inch provide extra toughness to the concrete. Chen et al. [106] reported that the polymer modification increases the concrete resistance to cracking. This happens due to particles polymerizing in the ITZ region by developing strong bond between cement paste matrix and aggregate. Brake et al. [37] found that the fracture toughness also to be dependent on size of specimen. Gesoglu et al. [101] mentioned in their study that fracture toughness increases when replacing fine aggregate \& coarse aggregate with crump rubber and tire chips.

Rehder et al. [95] found that the fracture toughness was primarily dependent on the porosity, even though toughness was found to increase with increase in fiber volume fraction. Gain in pore size; reduce the toughness value for a specific porosity. Applications of tire chips augment the fracture energy but shows reverse results for crumb rubber.

\subsection{Flexure fatigue}

Fatigue strength of a concrete material is determined by a two parameter Weibull probability function. Chen et al. [33] from their investigation stated that flexure fatigue test shows that Polymer modified NFC has far longer flexure fatigue life than supplementary cementitious modified NFC at all stressed level, as polymer helps in reduction of cracking or delay the cracking generation; moreover the fatigue life decreases with the increasing porosity and the stress level sustained by these specimens.

\subsection{Carbonation}

NFC due to its macro structure is highly inclined to carbonation and long term preservation to embedded steel is not possible. The process may starts in few weeks after surface exposure. The electrochemical measurement exhibit that proliferation of corrosion would be high for material dipped in water [88]. Enough data is not available to understand the behavior.

\subsection{Permeability}

The main function of NFC is the ability to pass water through interconnected network of pores. As per ACI 522R-08 the permeability of NFC lies between (1.4-12.2) mm/s. The hydraulic conductivity mainly depends upon porosity and the pore sizes [40]. Tests show that a minimum porosity of approximately $15 \%$ is required to achieve significant percolation. The permeability is inversely proportional to the strength properties [19,59]. Permeability is significantly influenced by the porosity [4] and not by the RCA [92]. Regardless of aggregate type and polymer type the coefficient of permeability increase as the total void ratio increase for all porous concretes [28]. Huang et al. [42] reported decrease in permeability due to incorporation of latex and sand in NFC.

The permeability or Hydraulic conductivity is calculated from the well-known Darcy law [51].The inertial and velocity effects were neglected in Darcy's law and these effects are prominent when the interconnected pores turn out to be larger in size. In order to take into account the nonlinearity, the Forcheimmer's equation and Izbash law/power law are useful $[119,120]$. Kozeny gave an equation to calculate permeability which was a function of porosity and specific surface area (later modified by Carmen) [121].

Chandrappa and Biligiri [51] investigated to validate the Darcy's law and K-C 
equation which provides correlation between permeability and pore structure features. Tortuosity and specific surface area are higher in smaller size aggregate and lesser in large size aggregate.

Later Sumanrooriya et al. [90] predicted permeability of NFC mixture through planar images of specimen and through experimental investigation and reported that they were in good agreement with each other. Since clogging is biggest threat for permeability, Alamd and Haselbach [122] studies different specifications and designs to make clogging resistant NFC.

The permeability of NFC can be measured by a simple apparatus shown in Fig. 10. In the absence of standard test method, different researches have used different apparatus based on their understanding [123].

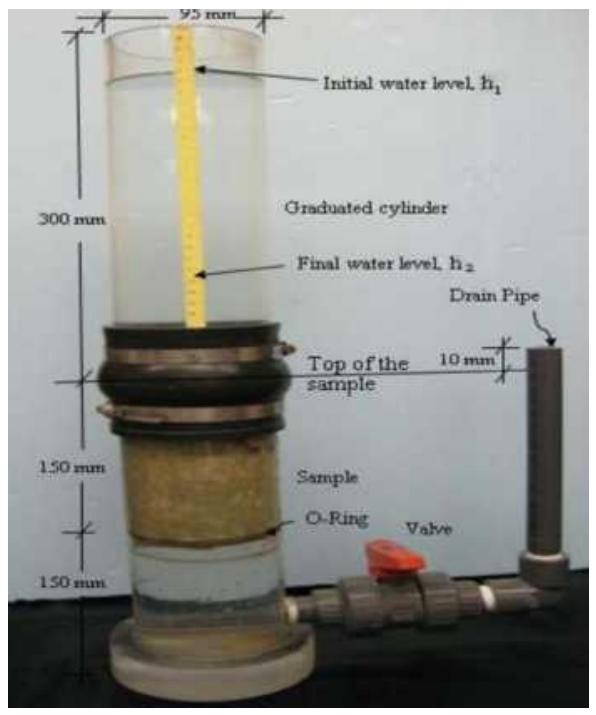

Figure 10: Falling head permeability apparatus [85]

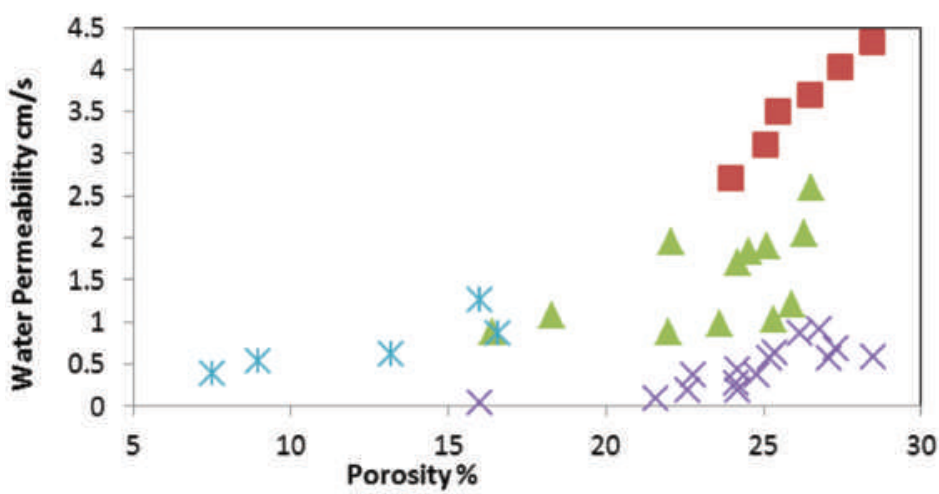

Bhutta et al. 2013

$\triangle$ L.A.Mata\& Leming, 2012

Neptune\& Putman, 2010

Lian \& Zhuge, 2010

Figure 11: Variation in water permeability v/s porosity from previous studies [124] 
From the trend obtained (Fig. 11), it is seen that permeability increases with increase in porosity. It is also reported that the permeability of concrete decreases with the increase of RHA amount until the optimum RHA amount is reached [34]. Also, constant head permeability appears to be a function of pasted drain down, effective air void content and void size in NFC specimen. The reserve of the falling head and constant head methods agree reasonably well for laboratory sample as widely reported [91, $63,125,101,124]$. In order to understand the microstructure, Bentz [144] through virtual model compared the percolation characteristics and transport properties of actual NFC and found to be closest to the actual PC. Also CT image (Computed tomography) and probalistic description method were utilized to analyze the microstructure and found that void distribution strongly affects strength and percolation [124].

\section{Water purification characteristics of NFC}

The runoff water carries different types of faecal matters, heavy and light chemicals, soil, oil, organic-inorganic residential and industrial wastes [126- 132]. The traditional pavements favor smooth runoff of water and as a result, the pollutants get passed on to water sources. If such pollutants pass on to ground then it pollutes ground water and imbalance the ecological system. The NFC reduces the quantity of such runoff water as well improve the quality of absorbed water reaching ground water resources.

High thickness of NFC acts as better purifier [133]. In one of studies, concentration of lead was negligible and copper and zinc were less in NFC [134, 135]. Dissolved heavy metal concentration was found to be very less in NFC [136]. NFC could be a very good option in industrial area to capture heavy metals. Ketcheson et al [129] reported that NFC can increase chloride contamination in salt vulnerable areas. Geotextile separate cadmium, zinc and copper [137, 138].

Table 4 shows different avenues considered for the advancement of properties of NFC.

Table 4: Different avenues considered for the advancement of properties of NFC

\begin{tabular}{|l|l|l|}
\hline Authors & Proposed methodology & \multicolumn{1}{|c|}{ Significance } \\
\hline $\begin{array}{l}\text { Bhutta } \text { et al. } \\
{[79]}\end{array}$ & $\begin{array}{l}\text { Three different aggregate } \\
\text { sizes along with SP and } \\
\text { cohesive agent }\end{array}$ & $\begin{array}{l}\text { High performance porous concrete (HPPC) } \\
\text { with blending of SP and cohesive agent. } \\
\text { Fair workability and strength properties. } \\
\text { Addition of cohesive agent decreases the total } \\
\text { void ratio and permeability. }\end{array}$ \\
\hline $\begin{array}{l}\text { Zhifu Yang } \\
{[33]}\end{array}$ & $\begin{array}{l}\text { Variation in w/c with } \\
\text { different combination of } \\
\text { silica Fume, fiber, AEA }\end{array}$ & $\begin{array}{l}\text { An increase in cement content slightly increased } \\
\text { the F-T Resistance of water-cured NFC. } \\
\text { Increasing w/c from 0.25 to 0.35, increase in } \\
\text { F-T resistance of both water and air cured } \\
\text { specimen observed. } \\
\text { Silica fume was observed to help increase the } \\
\text { F-T resistance of water-cured in the presence } \\
\text { of deicing salts whereas no significant effect } \\
\text { of polypropylene fibers. }\end{array}$ \\
\hline
\end{tabular}

ISSN No.: 232 1-3906 (Print) ISSN No.: 2321-7146 (Online) Registration No.: CHAENG/2013/51235 Periodicity: Bi-Annually 


\begin{tabular}{|c|c|c|}
\hline \multicolumn{3}{|c|}{ Table 4 [Continued $]$} \\
\hline $\begin{array}{l}\text { Li et al. } \\
{[139]}\end{array}$ & $\begin{array}{l}\text { Silica fume, fly ash (se- } \\
\text { lected as reactive powder), } \\
\text { U-type expansion agent } \\
\text { (UEA) (aluminum sulfate, } \\
\text { aluminum oxide and alumi- } \\
\text { num potassium sulfate) }\end{array}$ & $\begin{array}{l}\text { High Strength NFC with Optimum mix pro- } \\
\text { portion of Reactive powder } \\
\text { Compressive strength greatert than } 69 \mathrm{MPa} \\
\text { and flexural strength greater than } 10 \mathrm{MPa} \\
\text { with a } 13.02 \mathrm{~mm} / \mathrm{s} \text { permeability coefficient. }\end{array}$ \\
\hline $\begin{array}{l}\text { Shen et al. } \\
{[140]}\end{array}$ & $\begin{array}{l}\text { Application of } \mathrm{TiO} 2 \text { onto } \\
\text { the surface of } \mathrm{NFC}\end{array}$ & Excellent pollutant removal properties. \\
\hline $\begin{array}{l}\text { Tho-in et } \\
\text { al. [141] }\end{array}$ & $\begin{array}{l}\text { (FA), } \mathrm{Na}_{2} \mathrm{SiO}_{s}, \mathrm{NaOH} \text { solu- } \\
\text { tion and coarse aggregate } \\
\end{array}$ & Acceptable mechanical properties. \\
\hline $\begin{array}{l}\text { Nguyen et } \\
\text { al. [26] }\end{array}$ & $\begin{array}{l}60 \% \text { mass of the natural } \\
\text { aggregates was replaced } \\
\text { by crushed seashells and } \\
\text { about } 6 \% \text { of sand is used } \\
\text { to make shell NFC } \\
\end{array}$ & $\begin{array}{l}\text { The crushed shells have a lower mechanical } \\
\text { strength and freeze/thaw resistance than the } \\
\text { control NFC. } \\
\text { Significant decrease in permeability on loading } \\
\text { with mixture of silty clay and sand. }\end{array}$ \\
\hline $\begin{array}{l}\text { Murray et } \\
\text { al. [65] }\end{array}$ & $\begin{array}{l}\text { Chitosan (waste from sea food } \\
\text { industry) and tire crumb. }\end{array}$ & $\begin{array}{l}\text { Similar properties } \\
\text { High sorption capacity. }\end{array}$ \\
\hline $\begin{array}{l}\text { Sata et al. } \\
{[100]}\end{array}$ & $\begin{array}{l}\text { NA, RCA with fly ash } \\
(\mathrm{FA}),(\mathrm{Na} 2 \mathrm{SiO} 3) \&(\mathrm{NaOH}) \\
\text { solution }\end{array}$ & $\begin{array}{l}\text { Both Recycle aggregate from Concrete and } \\
\text { clay Bricks could be used. } \\
\text { Compressive strength of } 10.3 \mathrm{MPa} \text { with recy- } \\
\text { cle aggregate produced. }\end{array}$ \\
\hline $\begin{array}{l}\text { Zhong \& } \\
\text { Wille }[45]\end{array}$ & $\begin{array}{l}\text { SF, silica powder and ag- } \\
\text { gregates with } 99 \% \text { content } \\
\text { of } \mathrm{SiO}_{2} \text { along with high } \\
\text { range WR }\end{array}$ & $\begin{array}{l}\text { HPPC made with appropriate aggregate size } \\
\text { and a/b ratio. }\end{array}$ \\
\hline
\end{tabular}

\section{Summary and conclusion}

The review paper summarizes the detailed study on various parameters depicting the properties of $\mathrm{NFC}$ and its vital use for infiltrating water into the ground. It can be inferred that admixture such as RHA, FA, $\mathrm{SF}$ when added to concrete, have potential to increase mechanical and durability properties of NFA. As a result of which the microstructure of cement matrix will be modified in order to enhance the quality of concrete as mentioned in the above section. It has been observed from the previous studies that the effect of $\mathrm{w} / \mathrm{c}$ ratio is negligible on the strength of NFC which mainly depends on the mixed variables that are function of aggregate cement ratio. The resistance against aggressive chemicals has not been reported in past studies; hence it is required to investigate the pavement considering the long-term effect. The literature review reveals that a very few studies have been reported on carbonation of $\mathrm{NFC}$.

So, it can be concluded that the proper selection of mix variable is a major concern which dominates the strength property of NFC. In India, its testing is limited to R\&D labs only and practical application is still not on the ground. Regular maintenance of $\mathrm{NFC}$ pavement is required for the proper 
functioning. More practical research need to be conducted for the efficient use of NFC in pavements. A few of the future research aspects are described as following:

Research Scope in the field of NFC

- The knowledge of perdurable behavior of NFC using binary and ternary combination of mineral admixtures is relatively unknown.

- Investigation of mechanical properties and durability of no fine concrete on long term basis.

- Carbonation of NFC is not well defined.

- The response towards diverse cement blends on mechanical and durability properties of NFC need to be further probed.

- Optimization of mineral admixtures in mix design of NFC.

- Established mix design for the application on low volume traffic as well as for high volume traffics pavements.

- Standardized method to determine the porosity and permeability of no fine concrete.

- The durability property such as resistance against salts, Sulphate and acids is not studied.

\section{Acknowledgement}

This research did not receive any specific grant from funding agencies in the public, commercial, or not-for-profit sectors. The authors gratefully acknowledge the support of the staff of Concrete Structures Laboratories at Dr. B. R Ambedkar National Institute of Technology, Jalandhar, India during the experimentation work reported in the present investigation.

\section{References}

[1] ACI 522R-10. (Reapproved 2011), Report on pervious concrete, American
Concrete Institute, Farmington Hills, MI, USA, 2010.

[2] J. T. Kevern, "Evaluating permeability and infiltration requirements for pervious concrete", Journal of Testing Evaluation, vol. 43, no. 3, pp. 1-10, 2014.

[3] M. Sonebi, M. Bassuoni, and A. Yahia, "Pervious concrete: Mix design, properties and applications”, RILEM Technical Letters, pp. 109-115, 2015.

[4] A. Bonicelli, F. Giustozzi and M. Crispino, "Experimental study on the effects of fine sand addition on differentially compacted pervious concrete", Construction and Building Material. vol. 91, pp. 102-110, 2015.

[5] D. J. Swan and D. R. Smith, "Development of design system for permeable interlocking concrete pavement”, Green Streets and Highways 2010.

[6] X. Bao, W.Liao, Z.Dong, S.Wang and W.Tang, "Development of Vegetation- pervious concrete in Grid Beam System for Soil Slope Protection", Materials, vol. 10, 96, 2017.

[7] National Ready Mixed Concrete Association (NRMCA). CIP-38 - pervious concrete. Concrete in Practice. Silver Spring, MD, 2004.

[8] B. E. Eisenberg, ASCE - EWRI "Permeable pavement technical committee introduction of committee goals", and chapter 1 of Guidelines "Design Considerations Common to all Permeable Pavements", Low Impact Development 2010.

[9] A. Zouaghi, "Technological problems of multi-performance pervious concrete", In: Proceedings of the 1st fib congress, pp. 233-42, 2004.

[10] M. Chopra, M. Wanielista, J. Spence, 
C. Ballock, "University of Central Florida \& Florida DOT”, Construction and Maintenance Assessment of pervious concrete Pavements", 2007.

[11] M. T. Suleiman, K. Gopalakrishnan, J. T. Kevern, "Structural response of pervious concrete pavement systems using falling weight deflectometer testing and analysis", Journal of Transport Engineering, vol. 137, no. 12, pp. 907-917, 2017.

[12] I. K. Abite, M. Chopra, I. Uju, "Evaluation of mechanical properties and structural integrity for pervious concrete pavement systems", technical note, Journal of Material in Civil Engineering, vol. 26, pp. 1-6, 2014.

[13] M. Scholz, P. Grabowiecki, "Review of permeable pavement systems", Building and Environment, vol. 42, pp. 3830-3836, 2007.

[14] R. Gupta, "Monitoring in situ performance of pervious concrete in British Columbia- a pilot study", Case Studies in Construction Materials, vol. 1, pp. 1-9, 2014.

[15] L. M. Haselbach and R.M. Freeman, "Vertical porosity distributions in pervious concrete Pavement", ACI Materials Journal, vol. 103, no. 6, November- December 2006.

[16] W. B. Denison, "Performance of pervious portland cement concrete by field and laboratory testing, including void structure, Unit Weight, Compressive and Flexural Strength”, pervious concrete, Tampa. FL, pp.17-26, ASTM International, West Conshohocken, PA 2012.

[17] ASTM D448, "Standard classification for sizes of aggregates for roads and bridge construction”, ASTM International, 100 Barr Harbor Drive, PO Box C700, West Conshohocken,
PA 19428-2959, United States.

[18]. A. K. Jain, J. S. Chouhan, S. S. Goliya, "Effect of shape and size of aggregate on permeability of pervious concrete", Journal of Engineering Research and Studies, vol. 2, no. 4, pp. 48-51, 2011.

[19] A. I. Neptune and B. J. Putman, "Effect of aggregate size and gradation on pervious concrete mixtures", ACI Material Journal, vol. 107, no. 6, 2010.

[20] ASTM C29/C29M, "Standard test method for bulk density ("Unit Weight”) and Voids in Aggregate. ASTM International, 100 Barr Harbor Drive, PO Box C700, West Conshohocken, PA 19428-2959, United States.

[21] K. Cosic, L. Korat, V. Ducman, I. Netinger, "Influence of aggregate type and size on properties of pervious concrete", Construction and Building Materials, vol. 78, pp. 69-76, 2015.

[22] C. Gaedicke, A. Marines, F. Miankodila, "Assessing the abrasion resistance of cores in virgin and recycled aggregate pervious concrete", Construction and Building Materials, vol. 68, pp. 701708, 2014.

[23] H. K. Kim, H. K. Lee, "Influence of cement flow and aggregate type on the mechanical and acoustic characteristics of porous concrete", Applied Acoustics, vol. 71, pp. 607-615, 2010.

[24] Li J, "Mix design of pervious recycled concrete", in presented at the Geo Hunan International Conference, Changsha, China, June, 2009.

[25] R. Rizvi, S. Tighe, V.Henderson, J. Norris, "Evaluating the use of recycled concrete aggregate in pervious concrete pavement. Transportation Research Record”, 
Journal of Transport Research Board, no. 2164, pp. 132-40, 2010.

[26] D. H. Nguyen, Moh. Boutouil, N. Sebaibi, F. Baraud, L. Leleyter, "Durability of pervious concrete using crushed seashells", Construction and Building Materials, vol. 135, pp. 137-150, 2017.

[27] W. T. Kuo, C. C. Liu, D. S. Su, "Use of washed municipal solid waste incinerator bottom ash in pervious concrete", Cement Concrete Composites, vol. 37, pp. 328-335, 2013.

[28] M. A. R. Bhutta, N. Hasanah, N. Farhayu, M. W. Hussin, M. Bin, M. Tahir, J. Mirza, "Properties of porous concrete from waste crushed concrete (recycled aggregate)", Construction and Building Materials, vol. 47, pp. 12431248, 2013.

[29] M. Behera, S. K. Bhattacharyya, A.K. Minocha, R. Deoliya, S. Maiti, "Recycled aggregate from C\&D waste $\&$ its use in concrete - A breakthrough towards sustainability in construction sector: A review", Construction and Building Materials, vol. 68, pp. 501516, 2014.

[30] Y. Zaetang, A. Wongsa, V. Sata, P. Chindaprasirt, "Use of lightweight aggregates in pervious concrete", Construction and Building Materials, vol. 48, pp. 585-591, 2013.

[31] P. Chindaprasirt, P. Nuaklong, Y. Zaetang, P. Sujumnongtokul, V. Sata, "Mechanical and thermal properties of recycling lightweight pervious concrete", Arab Journal of Science and Engineering, 2014.

[32] J. Yang, G. Jiang, "Experimental study on properties of pervious concrete pavement materials", Cement and Concrete Research, vol. 33, pp. 381-386, 2003.
[33] Z. Yang, "Freezing-and-thawing durability of pervious concrete under simulated field conditions", $A C I$ Materials Journal, 2011.

[34] S. Hesami, S. Ahmadi and M. Nematzadeh, "Effects of rice husk ash and fiber on mechanical properties of pervious concrete pavement", Construction and Building Material, vol. 53, pp. 680-691, 2014.

[35] R. Zhong, K. Wille, "Compression response of normal and high strength pervious concrete", Construction and Building Material, vol. 109, pp. 177187, 2016.

[36] B. E. Jimma, P. R. Rangaraju, "Filmforming ability of flowable cement pastes and its application in mixture proportioning of Pervious concrete", Construction and Building Materials, vol. 71, pp. 273-282, 2014.

[37] N.A. Brake, H. Allahdadi, F. Adam, "Flexural strength and fracture size effects of pervious concrete", Construction and Building Materials, vol. 113, pp. 536-543,2016.

[38] X. Shu, B. Huang, H. Wu, Q. Dong, E.G. Burdette, "Performance comparison of laboratory and field produced Pervious concrete mixtures", Construction and Building Materials, vol. 25, pp. 3187-3192, 2011.

[39] M. Vancura, K. Macdonald, L. Khazanovich, "Microscopic analysis of paste and aggregate distresses in Pervious concrete in a wet, hard freeze climate", Cement \& Concrete Composites, vol. 33, pp. 1080-108, 2011.

[40] R. C. Meininger, "No-fines Pervious concrete for paving", Concrete International, vol. 10, no. 8, pp. 20-27, 1988.

[41] D. H. Nguyen, M. Boutouil, N. Sebaibi, L. Leleyter and F. Baraud, 
"Valorization of seashell by products in pervious concrete pavers", Construction and Building Materials, vol. 46, pp. 151-160, 2013.

[42] B. Huang, H. Wu, X. Shu, E.G. Burdette, "Laboratory evaluation of permeability and strength of polymer-modified pervious concrete", Construction and Building Materials, vol. 24, pp. 818-823, 2010.

[43] C. Lian, Y. Zhuge, S. Beecham, "The relationship between porosity and strength for pervious concrete", Construction and Building Materials, vol. 25, pp. 4294-4298, 2011.

[44] M. Uma Maguesvari, V.L. Narasimha, "Studies on characterization of pervious concrete for pavement applications", Procedia - Social and Behavioral Sciences, vol. 104, pp. 198 207, 2013.

[45] R. Zhong, K. Wille, "Material design and characterization of highperformance Pervious concrete", Construction and Building Materials, vol. 98, pp. 51-60, 2013.

[46] D. H. Nguyen, N. Sebaibi, M. Boutouil, L. Leleyter, F. Baraud, "A modified method for the design of Pervious concrete mix", Construction and Building Materials, vol. 73, pp. 271-282, 2014.

[47] Li J, "Mix design of pervious recycled concrete", in Geo Hunan international conference, Changsha, China, June, 2009.

[48] M. Zheng, S. Chen and B. Wang, "Mix design method for permeable base of porous concrete", International Journal of Pavement Research Technology, vol. 5, no. 2, pp. 102-107, 2012.

[49] V.Schaefer, K. Wang, M. Suleiman, and J. Kevern, "Mix design development for pervious concrete in cold weather climates", Center for Transportation Research and Education 2006, Iowa State University 2901 South Loop Drive, Suite 3100.

[50] E. Khankhaje, M. R. Salim, J. Mirza, M.W. Hussin, M. Rafieizonooz, "Properties of sustainable lightweight Pervious concrete containing oil palm kernel shell as coarse aggregate", Construction and Building Materials, vol. 126, pp. 1054-1065, 2016.

[51] A. K. Chandrappa, K. P. Biligiri, "Comprehensive investigation of permeability characteristics of pervious concrete- A hydrodynamic approach”, Construction and Building Materials, vol. 123, pp. 627-637, 2016.

[52] A. Yahia, K. D. Kabagire, "New approach to proportion pervious concrete", Construction and Building Materials, vol. 62, pp. 38-46, 2014.

[53] E. Lim, K. H. Twan, T. F. Fwa, "Effect of mix proportion on strength and permeability of pervious concrete for use in pavement", in Proceedings of the Eastern Asia Society for Transportation Studies, vol. 9, 2013.

[54] M. T. Bassuoni, M. Sonebi, "Pervious concrete: a sustainable drainage solution", The Concrete Society, vol. 44, pp. 14-16, 2010.

[55] N. Neithalath, M.S. Sumanasooriya, O. Deo, "Characterizing pore volume, sizes, and connectivity in pervious concretes for permeability prediction", Material Characterization, vol. 61, pp. 802-813, 2010.

[56] J. T. Kevern, K. Wang and V. R. Schaefer, "Effect of Coarse Aggregate on the Freeze-Thaw Durability of Pervious concrete", Journal of Materials in Civil Engineering, vol. 22, pp. 469-475, 2010.

[57] L.K. Crouch, J.Pitt, Hewitt, "Aggregate 
effects on pervious Portland cement concrete static modulus of elasticity", Journal of Materials in Civil Engineering, vol. 19, pp. 561-568, 2007.

[58] N. Ghafoori, S. Dutta, "Laboratory investigation of compacted nofines concrete for paving materials", Journal of Materials in Civil Engineering, vol. 7, no. 3, pp. 183-191, 1995.

[59] A. Joshaghani, A. Akbar Ramezanianpour, O. Ataei, A. Golroo, "Optimizing pervious concrete pavement mixture design by using the taguchi method", Construction and Building Materials, vol. 101, pp. 317325, 2015.

[60] NRMCA, 2004, "Concrete in practice: What, Why and How? CIP- 38 Pervious concrete", National Ready Mixed Concrete Association, Silver Spring, MD.

[61] P. D. Tennis, M. L. Leming and D. J. Akers, "Pervious concrete pavements," portland cement association, Skokie, IL, and National Ready Mixed Concrete Association, Silver Spring, MD, pp. 28, 2004.

[62] C. Gaedicke, A. Marines, F. Miankodila, "A method for comparing cores and cast cylinders in virgin and recycled aggregate pervious concrete", Construction and Building Materials, vol. 52, pp. 494-503, 2014.

[63] A. Ibrahim, E. Mahmoud, Moh. Yamin and V. C. Patibandla, "Experimental study on portland cement pervious concrete mechanical and hydrological properties", Construction and Building Materials, vol. 50, pp. 524-529, 2014.

[64] B. J. Putman, A. I. Neptune, "Comparison of test specimen preparation techniques for pervious concrete pavements", Construction and
Building Materials, vol. 25, pp. 34803485, 2011.

[65] C. A. Murray, K.S. Snyder and B.A. Marion, "Characterization of permeable pavement materials based on recycled rubber and chitosan", Construction and Building Material, vol. 69, pp. 221-231, 2014.

[66] L. K. Crouch, J. P. Hendrix, A. Sparkman and D. Badoe, "Variability of fresh and hardened voids of pervious concrete”, 2012 by ASTM International, 100 Barr Harbor Drive, PO Box C700, West Conshohocken, PA, 19428-2959.

[67] L. M. Haselbach and R. M. Freeman, "Effectively estimating in situ porosity of pervious concrete from Cores", Journal of ASTM International, vol. 4, no. 7, 2007

[68] ASTM C1688, "Standard test Method for density and void content of Freshly mixed pervious concrete", ASTM International, 100 Barr Harbor Drive, PO Box C700, West Conshohocken, PA 19428-2959, United States.

[69] F. Montes, S.Valavala and L.M. Haselbach, "A new test method for porosity measurements of portland cement pervious concrete", Journal of ASTM International, vol. 2, no. 1, 2005.

[70] ASTM C1754, ASTM International, 100 Barr Harbor Drive, PO Box C700, West Conshohocken, PA 19428-2959, United States.

[71] C. Gaedicke, A. Torres, K.C.T. Huynh and A. Marines, "A method to correlate splitting tensile strength and compressive strength pervious concrete cylinders and cores", Construction and Building Materials, vol. 125, pp. 271-278, 2016.

[72] L.A. Mata and M. L. Leming, "Vertical 
distribution of sediments in pervious concrete pavement systems", ACI Material Journal, vol. 109, no. 2, March-April 2012.

[73] W. D. Martin III, N. B. Kaye and B.J. Putman, "Impact of vertical porosity distribution on the permeability of Pervious concrete", Construction and Building Materials, vol. 59, pp. 78-84, 2014.

[74] H.Wu, B. Huang, X. Shu and Q. Dong, "Laboratory evaluation of abrasion resistance of portland cement pervious concrete", Journal of Material in Civil Engineering, vol. 23, pp. 697-702, 2014.

[75] L. K. Crouch, M. A. Cates, V. James Dotson, K. R. Honeycutt and D. A. Badoe, "Measuring the effective air void content of portland cement pervious pavements", Cement Concrete and Aggregates, vol. 25, no. 1, 2003.

[76] ASTM D7063, "Standard test method for effective porosity and effective air voids of compacted bituminous paving mixture samples," ASTM International, West Conshohocken, PA, pp. 4.

[77] O. Deo, N. Neithalath, "Compressive response of pervious concrete proportioned for desired porosities", Construction and Building Materials, vol. 25, pp. 4181-4189, 2011.

[78] S. Meulenyzer, E. Stora, F. Perez, "Impact of pervious concrete porosity on permeability by 3d image analysis", 2012, ASTM International, 100 Barr Harbor Drive, PO Box C700, West Conshohocken, PA.

[79] A. R. Bhutta, K. Tsuruta and J. Mirza, "Evaluation of high-performance Pervious concrete properties", Construction and Building Materials, vol. 31, pp. 67-73, 2012.
[80] L. M. Haselbach and R. M. Freeman. "Vertical porosity distributions in pervious concrete pavement", $A C I$ Materials Journal, vol. 103, no. 6, 2006.

[81] J. T. Kevern, "Advancements in pervious concrete technology", $\mathrm{PhD}$. Thesis, Iowa State University, 2014.

[82] R. Zhong and K. Wille, "Linking pore system characteristics to the compressive behavior of pervious concrete", Cement and Concrete Composites, vol. 70, pp. 130-138, 2016.

[83] O. Deo and N. Neithalath, "Compressive behavior of pervious concrete and a quantification of the influence of random pore structure features", Materials Science and Engineering, vol. 528, pp. 402-412, 2010.

[84] C. Lian, Y.Zhuge, "Optimum mix design of enhanced permeable concreteAn experimental investigation", Construction and Building Materials, vol. 24, pp. 2664-2671, 2010.

[85] H. Li, J. Harvey and Z. Ge, "Experimental investigation on evaporation rate for enhancing evaporative cooling effect of permeable pavement materials", Construction and Building Materials, vol. 65, pp. 367-375, 2014.

[86] C. Syrrakou and G. F. Pinder, "Experimentally determined evaporation rates in pervious concrete systems", Journal of Irrigation Drain Engineering; vol. 140, 2014.

[87] F. Giustozzi, "Polymer modified Pervious concrete for durable and sustainable transportation infrastructures", Construction and Building Materials, vol. 111, pp. 502512, 2016.

[88] M. Carsana, F. Tittarelli and L. Bertolini, "Use of no-fines concrete 
as a building material, Strength, durability properties and corrosion protection of embedded steel", Cement Concrete Research, vol. 48, pp. 64-73, 2013.

[89] A. Torres, J. Hub, Jiong. \& A. Ramos, "The effect of the cementitious paste thickness on the performance of Pervious concrete", Construction and Building Materials, vol. 95, pp. 850859, 2015.

[90] M. S. Sumanasooriya and N. Neithalath, "Stereology and morphology based pore structure descriptors of enhanced porosity (pervious) concretes", ACI Materials Journal, vol. 106, no. 5, 2009.

[91] L. K. Crouch, J. Pitt and Hewitt, "Aggregate effects on pervious Portland cement concrete static modulus of elasticity", Journal of Material in Civil Engineering, vol. 19, pp. 561-568, 2007.

[92] R. Sriravindrarajah, N. D. H. Wang, and L. J. W. Ervin, "Mix design for pervious recycled aggregate concrete", International Journal of Concrete Structures and Materials, vol. 6, no. 4, pp. 239-246, 2012.

[93] J. J. Chang, W. Yeih, T. J. Chung and R. Huang, "Properties of pervious concrete made with electric arc furnace slag and alkali-activated slag cement", Construction and Building Materials, vol. 109, pp. 34-40, 2016.

[94] M. Suozzo and M. M. Dewoolkar, "Evaluation of strength and hydraulic testing methods of pervious concrete", ACI Materials Journal, vol. 111, no. 1, 2014.

[95] B. Rehder, K. Banh and N. Neithalath, "Fracture behavior of pervious concrete: The effects of pore structure and fibers", Engineering Fracture
Mechanics, vol. 118, pp. 1-16, 2014.

[96] M. Rangelov, S. Nassiri, Z. Chen, M. Russell and J. Uhlmeyer, "Quality evaluation tests for pervious concrete pavements placement", International Journal of Pavement and Research Technology, 2017.

[97] A. Hasnat, T. U. Mohammed, M. N. Hossain, N. Rahman, H. Hamada," Investigation of pervious concrete made with locally available materials", Third International Conference on Construction in Developing Countries (ICCIDC-III) "Advancing and Integrating Construction Education, Research \&' Practice" July 4-6, 2012 Bangkok, Thailand.

[98] M. H. Wu, C. L. Lin, W. C. Huang, J. W. Chen, "Characteristics of pervious concrete using incineration bottom ash in place of sandstone graded material", Construction and Building Materials, vol. 111, pp. 618-624, 2016.

[99] J. T. Kevern, K. Wang and V. R. Schaefer, "Effect of coarse aggregate on the freeze-thaw durability of pervious concrete", Journal of Material in Civil Engineering, vol. 22, pp. 469-475, 2010.

[100] V. Sata, A. Wongsa and P. Chindaprasirt, "Properties of pervious geopolymer concrete using recycled aggregates", Construction and Building Materials, vol. 42, pp. 33-39, 2013.

[101] M. Gesoglu, E. Guneyisi, G. Khoshnaw and S. Ipek, "Investigating properties of pervious concrete containing waste tire rubbers", Construction and Building Materials, vol. 63, pp. 206-213, 2014.

[102] N. Delatte, A. Mrkajic and D. Miller, "Field and laboratory evaluation of Pervious concrete pavements, Transportation Research Record: 
Journal of Transport and Research Board, vol. 2113 , pp. 132-139, 2010

[103] L. K. Crouch, N. Smith, A.C. Walker, T.R. Dunn and A. Sparkman, "Determining pervious pcc permeability with a simple triaxial flexible wall constant head permeameter", TRB 85th Annual Meeting Compendium of Papers, 2006.

[104] American Concrete Institute, "Building code requirements for structural concrete and commentary (318-11)", American Concrete Institute, Farmington Hills, Mich., pp. 503, 2011.

[105] ACI 363R-92 (Reapproved 1997), "State-of-the-Art report on highstrength concrete", reported by ACI Committee 363, American Concrete Institute ACI, pp. 25, 1997.

[106] Y. Chen, K. Wang, X. Wang and W. Zhou, "Strength, fracture and fatigue of pervious concrete", Construction and Building Materials, vol. 42, pp. 97104, 2013.

[107] J. T. Kevern, V. R. Schaefer, K.Wang, "The effect of curing regime on pervious concrete abrasion resistance", Journal of Testing and Evaluation, vol. 37, no. 4, 2009.

[108] D. Breton, A. C. Gibergues, G. Ballivy and J. Grandet, "Contribution to the formation mechanism of the transition zone between rock-cement paste", Cement and Concrete Research, vol. 23, pp. 335-46, 1993.

[109] J. L. Clarke, "Structural Lightweight Aggregate Concrete”, 1st ed. London: Blackie Academic \& Professional, 1993.

[110] C. Rocco and M. Elices, "Effect of aggregate shape on the mechanical properties of a simple concrete", Engineering Fracture Mechanics, vol.
76, pp. 286-98, 2009.

[111] J. T. Kevern, K. Wang and V. R. Schaefer, "Test methods for characterizing air void systems in portland cement pervious concrete", ASTM International, 100 Barr Harbor Drive, PO Box C700, West Conshohocken, PA 19428-2959, 2009.

[111] K. Wang, V. R. Schaefer and J. T. Kevern, M.T Suleiman, "Development of mix proportion for functional and durable pervious concrete". Proceedings of the NRMCA concrete technology forum; focus on pervious concrete 2006, Nashville, T.N, pp. 12.

[113] Z. Yang, H. Brown and A. Cheney, "Influence of moisture condition of freeze and thaw durability of Portland cement Pervious concrete", Proceedings of the NRMCA concrete technology forum; focus on Pervious concrete, pp. 15, 2006.

[114] M. Offenberg, "Development of a new test method for assessing the potential raveling resistance of pervious concrete", ASTM International, 100 Barr Harbor Drive, PO Box C700, West Conshohocken, PA 19428-2959, 2012.

[115] Q. Dong, H. Wu, B. Huang, X. Shu and K. Wang, "Investigation into laboratory abrasion test methods for pervious concrete", Journal of Material in Civil Engineering, vol. 25, pp. 886-892, 2013.

[116] Q. Dong, H.Wu, B. Huang and X. Shu, "Development of a simple and fast test method for measuring the durability of Portland cement Pervious concrete", Report portland cement association, 2010.

[117] C. Yu, W.K. Jin and Z.W. fang, "Evaluation of surface textures and skid resistance of pervious concrete 
pavement", Journal of Central South University, vol. 20, pp. 520-527, 2013.

[118] ASTM C1399/07a, Standard test method for obtaining average residual-strength of fiber-reinforced concrete", ASTM International, 100 Barr Harbor Drive, PO Box C700, West Conshohocken, PA 19428-2959, United States.

[119] C. Bordier and D. Zimmer, "Drainage equations and non- darcian modelling in coarse porous media or geosynthetic materials", Journal of Hydrology, vol. 228, pp. 174-187, 2000.

[120] F. Thauvin and K.K. Mohanty, "Network modeling of non-Darcy flow through porous media", Transport in Porous Media, vol. 31, pp. 19-37, 1998.

[121] H. G. Sizemore, "Soil permeability: accuracy of the Kozeny- Carman equation in shallow flow problems on mars and earth", 45th Lunar and Planetary Science Conference, paper no. 1902, 2014.

[122] A. Alamd and L. Haselbach, "Estimating the modulus of elasticity of pervious concrete based on porosity", Advances in Civil Engineering Materials, 2014 ASTM International, 100 Barr Harbor Drive, P.O. Box C700, West Conshohocken, PA 19428-2959.

[123] O. Deo, M. Sumanasooriya and N. Neithalath, "Permeability reduction in pervious concretes due to clogging, experiments and modeling", Journal of Material in Civil Engineering, vol. 22, pp. 741-751, 2010.

[124] S.Y. Chung, T. S. Han, S. Y. Kim, and T. H. Lee, "Investigation of the permeability of porous concrete reconstructed using probabilistic description methods", Construction and Building Materials, vol. 66, pp. 760-
$770,2014$.

[125] M. Sonebi, M. T. Bassuoni, "Investigating the effect of mixture design parameters on pervious concrete by statistical modeling", Construction and Building Materials, vol. 38, pp. 147-154, 2013.

[126] EBP 322, Storm water guidelines, Water security Agency, 2014.

[127] D. Li, J. Wan, Y. Ma, Y. Wang, M. Huang and Y. Chen, "Stormwater runoff pollutant loading distributions and their correlation with rainfall and catchment characteristics in a rapidly industrialized city”, vol. 3, 2015.

[128] J. T. Thomle, "The declining ph of waters exposed to pervious concrete" (Master thesis)", Washington State Univ., Department of Civil and Environmental Engineering, 2010.

[129] S. J. Ketcheson, J. S. Price, S. L.Tighe and M. Stone, "Transport and retention of water and salt within pervious concrete pavements subjected to freezing and sand application", Journal of Hydrological Engineering, vol. 19, no. 11, 2014.

[130] B. J. D'Arcy, F. Usman, D.Griffiths and P. Chatfield, "Initiatives to tackle diffuse pollution in the UK", Water Science and Technology, vol. 38, no. 10, pp. 131-138, 1998.

[131] NCDENR, "Updated draft manual of storm water best management practices", Public consultation document DOC-7-1. Division of Water Quality, NC, USA: North Carolina Department of Environment and Natural Resources (NCDENR), 2005.

[132] A. K. Chandrappa and K. P. Biligiri, "Pervious concrete as a sustainable pavement material - Research Findings and future prospects: A state-of-theart review", Construction and Building 
Materials, vol. 111, pp. 262-274, 2016.

[133] M. G. Lee, M. Tia, S. H. Chuang, Y. Huang and C.L. Chiang, "Pollution and purification study of the Pervious concrete pavement material”, Journal of Material in Civil Engineering, vol. 26, no. 8, 2013.

[134] L. Haselbach, C. Poor and J. Tilson, "Dissolved zinc and copper retention from stormwater runoff in ordinary Portland cement pervious concrete", Construction and Building Materials, vol. 53, pp. 652-657, 2014.

[135] B. O. Brattebo and D. B. Booth, "Longterm storm water quantity and quality performance of permeable pavement systems", Water Research, vol. 37, no. 26, pp. 4369-76, 2003.

[136] C. Dierkes, L. Kuhlman, J. Kandasamy and G. Angelis, "Pollution retention capability and maintenance of permeable pavements", in Proceedings of the ninth international conference on urban drainage, Portland, USA, 8-13 September 2002.

[137] G. M. Kim, J. G. Jang, H. R. Khalid and H. K. Lee, "Water purification characteristics of Pervious concrete fabricated with CSA cement and bottom ash aggregates", Construction and Building Materials, vol. 136, pp. 1-8, 2016.

[138] M. Legret, V. Colandini and C. Lemarc, "Effects of a porous pavement with reservoir structure on the quality of runoff water and soil", Science of the Total Environment, vol. 190, pp. 33540, 1996.

[139] J. Li, Y. Zhang, G. Liu and X. Peng, "Preparation and performance evaluation of an innovative pervious concrete pavement", Construction and Building Materials, vol. 138, pp. 479-485, 2017.

[140] S. Shen, M. Burton, B. Jobson and L.
Haselbach, "Pervious concrete with titanium dioxide as a photo catalyst compound for a greener urban road environment", Construction and Building Materials, vol. 35, pp. 874-883, 2012.

[141] T. Tho-in, V. Sata, P. Chindaprasirt and C. Jaturapitakkul, "Pervious highcalcium fly ash geopolymer concrete", Construction and Building Materials, vol. 30, pp. 366-371, 2012.

[142] E. Guneyisi, M. Gesoglu, Q. Kareem, S. Ipek, "Effect of different substitution of natural aggregate by recycled aggregate on performance characteristics of pervious concrete", Material and Structures, 2014.

[143] F. Tittarelli, M. Carsanaa and M. L. Ruello, "Effect of hydrophobic admixture and recycled aggregate on physical-mechanical properties and durability aspects of no-fines concrete", Construction and Building Materials, vol. 66, pp. 30-37, 2014.

[144] D. P. Bentz, "Virtual pervious concrete: Microstructure, percolation, and permeability", ACI Material Journal, vol. 105, no. 3, 2008.

[145] Z. Zhang, Y. Zhang, C. Yan and Y. Liu, "Influence of crushing index on properties of recycled aggregates Pervious concrete", Construction and Building Materials, vol. 135, pp. 112$118,2017$. 